\title{
APLIKASI ULANG AZOSPIRILLUM TERSELEKSI PADA TANAMAN CABAI MERAH (Capsicum annum, L) YANG DITANAM PADA ULTISOL
}

\author{
Imra Atil Mardya ${ }^{1}$, Gusmini, Agustian ${ }^{2 *}$ \\ 1) Program Studi Magister Ilmu Tanah Fakultas Pertanian Universitas Andalas \\ 2) Laboratorium Biologi Tanah, Fakultas Pertanian Universitas Andalas \\ Kampus Limau Manis (25163) Padang, \\ Sumatera Barat-Indonesia \\ *Corresponding author: tel +62(0)75172773; fax +62(0)75172702 \\ Email:agustian@agr.unand.ac.id
}

\begin{abstract}
The endophytic bacteria are bacteria whose life cycle is partially or completely associated in the host plant tissue in various kinds of relationships (symbiosis) that it undergoes. The potential of endophytic bacteria as microbial resources is widely used as a biological control for plants, including as the producer of phytohormones and the agent of biocontrol and biofertilizer. This study aims to test selected endophyte bacterial isolates from chili as a biofertilizer to meet the nutrient requirements that are useful during the vegetative growth period of red chili in Ultisols. The study used a completely randomized design with 4 treatments and 3 replications, namely $\mathrm{A}=$ fertilizer $\mathrm{N}$ recommendation; $\mathrm{B}=$ Azospirillum $\mathrm{sp} \mathrm{AK}+$ Fertilizer $\mathrm{N}$ recommendation; $\mathrm{C}=$ Azospirillum $\mathrm{sp}$ $\mathrm{BT}+$ Fertilizer $\mathrm{N}$ recommendation; $\mathrm{D}=$ Azospirillum sp $\mathrm{DN}+$ fertilizer $\mathrm{N}$ recommendation. Azospirillum sp AK and Azospirillum sp DN isolates gave better vegetative growth than those of Azospirillum sp BT isolates with average dry weight, respectively, $19.49 \mathrm{~g}$ and $18.93 \mathrm{~g}$ and with a height of $29.67 \mathrm{~cm}$ and $29.60 \mathrm{~cm}$. The superiority of the 2 isolates was also shown in the observation of the number of leaves 30.39 and 22.50 and the number of branches 6.45 and 6.28 respectively for Azospirillum sp AK and Azospirillum sp DN isolates.
\end{abstract}

Key words : Endophytic bacteria, red chili, Ultisols

(C) 2020 Mardya, Gusmini, Agustian

\section{PENDAHULUAN}

Cabai merah (Capsicum annum, L) adalah salah satu komoditi hortikultura yang potensial dikembangkan di Indonesia dan bernilai ekonomi tinggi karena sangat dibutuhkan dalam pemenuhan kebutuhan konsumsi nasional maupun komoditas ekspor, sehingga memacu minat petani untuk melakukan peningkatan produksi. Berbagai upaya telah dilakukan dalam pengembangan produksi namun berdasarkan data BPS (2019), produksi cabai merah masih mengalami penurunan sebesar 0.09 ton/ha dari produksi 1,21 juta ton pada tahun 2017 menjadi 1,12 juta ton pada tahun 2019 (Pusat Pengkajian Perdagangan Dalam Negeri, 2019).

Penurunan produktivitas cabai merah disebabkan karena kurang tersedianya lahan subur serta tingginya biaya produksi akibat penggunaan pupuk kimia sintetik selama masa tanam. Indonesia merupakan negara sub tropis dengan total lahan subur berkisar $25-30 \%$ selebihnya didominasi oleh tanah yang sudah mengalami pelapukan lanjut salah satunya Ultisol. 
Ultisol merupakan tanah tua yang mempunyai sebaran luas 45.794.000 ha dari total daratan Indonesia sehingga upaya pengembangan dan peningkatan produkai cabai merah dapat diarahkan pada Ultisols. Dalam pemanfaatannya sebagai lahan budidaya, Ultisols memiliki kendala kondisi tanah yang tidak subur mulai dari reaksi tanah $(\mathrm{pH})$ Ultisols $<5,5$ (kriteria agak masam), konsentrasi Alumunium yang tinggi, kandungan bahan organik rendah, kejenuhan basa $\mathrm{KB}<35 \%$ (Paiman dan Armadon, 2010). Untuk meningkatkan produktivitas cabai merah yang ditanam di Ultisols diperlukan beberapa alternatif agar tanaman dapat tumbuh dengan optimal. Pengapuran merupakan salah satu upaya dalam mengatasi kemasaman tanah dengan menaikkan $\mathrm{pH}$, mengurangi kejenuhan $\mathrm{Al}$, menambah unsur $\mathrm{Ca}, \mathrm{Mg}$ dan $\mathrm{P}$ serta membantu memperbaiki kondisi lingkungan mikroorganisme tanah. Selain itu, pemakaian pupuk kimia sintetik juga merupakan salah satu upaya yang selalu dilakukan petani dalam memenuhi kebutuhan hara tanaman untuk mencapai produktivitas yang tinggi, namun secara efektifitas dan efisiensinya penggunaan pupuk kimia sintetik secara intensif tanpa dosis yang tepat menyebabkan kerusakan lingkungan dan tingginya biaya produksi. Untuk meningkatkan produktivitas cabai yang ramah lingkungan diperlukan berbagai teknologi diantaranya teknologi pegelolaan tanaman dan sumberdaya terpadu (PTT). Salah satu alternatif yang dapat dilakukan yaitu dengan pemanfaatan agen biofertilizer bakteri endofit. Bakteri endofit adalah bakteri yang sebagian atau seluruh siklus hidupnya berasosiasi didalam jaringan tanaman inang dan umumnya bersifat mutualistik tanpa menimbulkan infeksi pada tanaman inang (Sturz dan Nowak, 2000). Potensi bakteri endofit sebagai sumberdaya mikroba banyak dimanfaatkan dalam pengendalian penyakit tanaman secara hayati (Larran et al, 2016; Cocq et al, 2017), mampu memfiksasi nitrogen dan melarutkan posfat (biofertilizer), serta sebagai penghasil fitohormon (Leite et al, 2018). Pada penelitian ini dilakukan pengujian terhadap bakteri endofit terseleksi asal cabai sebagai biofertilizer untuk memenuhi kebutuhan hara yang berguna pada masa pertumbuhan vegetatif cabai merah di Ultisols.

\section{BAHAN DAN METODA}

Alat yang digunakan pada penelitian ini adalah alat-alat umum yang digunakan pada laboratorium mikrobiologi dan laboratorium kimia tanah dan alat khusus yang dibutuhkan untuk penelitian ini yaitu stirrer, autoklaf, inkubator (4$80^{\circ} \mathrm{C}$ ), laminar air flow, ph meter, spektrofotometer dan AAS. Bahan dasar yang digunakan pada penelitian ini adalah isolat bakteri endofit Azospirillum sp AK, Azospirillum sp BT dan Azospirillum sp DN yang diperoleh dari hasil isolasi dari tanaman cabai. Contoh Ultisol digunakan sebagai media tanam dalam percobaan ini. Benih cabai merah yang dipakai dalam percobaan ini adalah non hibrida varietas Laris.

Metoda pada penelitian ini menggunakan Rancangan Acak Lengkap (RAL) $4 \times$ 3. Perlakuan yang diberikan adalah $\mathrm{A}=$ Pupuk $\mathrm{N}$ rekomendasi; $\mathrm{B}=$ Bakteri endofit $\mathrm{AK}+$ Pupuk $\mathrm{N}$ rekomendasi; $\mathrm{C}=$ Bakteri endofit $\mathrm{BT}+$ Pupuk N rekomendasi; $\mathrm{D}=$ Bakteri endofit $\mathrm{DN}+$ Pupuk N rekomendasi. Setiap unit percobaan terdiri dari tiga ulangan sehingga diperoleh 12 total unit sampel percobaan. Percobaan dilakukan sampai tanaman memasuki fase vegetatif (35 HST), setelah itu dilanjutkan dengan analisis kimia tanah dan tanaman. 
Contoh tanah Ultisol diambil dari Kebun Percobaan Fakultas Pertanian Universitas Andalas Padang. Pengapuran tanah menggunakan kapur dolomit setara 1,5 Al- dd. Jumlah tanah sebagai media tumbuh cabai adalah sebanyak $8 \mathrm{~kg}$ setara berat kering mutlak yang dimasukkan pada polybag ukuran 30 x $50 \mathrm{~cm}$. Inkubasi kapur dilakukan selama 2 minggu dalam keadaan kapasitas lapang. Sampel tanah diambil sebanyak $200 \mathrm{~g}$ diambil sebelum dan setelah inkubasi untuk keperluan analisis kimia tanah. Sebelum dibibitkan, benih cabai direndam terlebih dahulu selama 6 jam kedalam suspensi bakteri Azospirillum $s p$ AK (isolat endofit akar), BT (isolat endofit batang) dan DN (isolat endofit daun) dengan kerapatan populasi $10^{8} \mathrm{ml}^{-1}$. Bibit dipindahkan ke polybag setelah berumur 21 hari yaitu setelah masa inkubasi kapur pada tanah berakhir. Dalam percobaan ini tanaman dipupuk dengan pupuk ZA setara rekomendasi pemupukan cabai (3.01 g/polybag setara $99 \mathrm{~kg} / \mathrm{ha})$, SP36 1x rekomendasi (4.51 g/polybag setara 149 $\mathrm{kg} / \mathrm{ha}$ ) dan KCL 1x rekomendasi (4.51 $\mathrm{g} /$ polybag setara $149 \mathrm{~kg} / \mathrm{ha}$ ) yang dibagi menjadi tiga kali waktu pemberian. Pemeliharaan dilakukan dengan penyiraman, pengendalian gulma serta pengendalian penyakit tanaman.

Variabel pengamatan terdiri dari analisis kimia tanah $(\mathrm{pH}$, P-tersedia, Corganik, N-total, Al-dd, K, Ca dan Mg-dd) dan pengamatan pertumbuhan tanaman. Hasil yang diperoleh diuji dengan statistik dilanjutkan dengan uji Duncan's New Multiple Range Test (DNMRT) pada taraf $5 \%$.

\section{HASIL DAN PEMBAHASAN Analisis Kimia Tanah}

Dari hasil analisis kimia tanah di laboratorium yang tertera pada Tabel 1, terlihat bahwa Ultisol yang digunakan memiliki tingkat kesuburan yang rendah dan tergolong dalam $\mathrm{pH}$ masam (4.7). Reaksi tanah yang masam disebabkan daerah pengambilan sampel tanah beriklim tropis dengan curah hujan tinggi,menyebabkan kation basa ditanah mengalami leaching kemudian hilang bersama aliran permukaan sehingga kompleks jerapan liat didominasi oleh kation bereaksi masam dan bervalensi tinggi $\left(\mathrm{Al}^{3+}\right)$ dengan nilai yang terhitung $1.86 \mathrm{me} / 100 \mathrm{~g}$ (Thomas et al, 2007). Rendahnya kation basa Ultisols terlihat dari Tabel 1, nilai K-dd, Ca-dd, Mg-dd terhitung masing-masing $0.28 ; 1.24 ; 0.45$ me/100 g dengan kriteria rendah s.d sangat rendah. Al-dd yang terjerap dipermukaan koloid tanah akan mengalami hidrolisis saat bereaksi dengan air hujan menyumbangkan ion $\mathrm{H}^{+}$penyebab kemasaman tanah, disamping itu keracunan alumunium ditanah juga menyebabkan defisiensi unsur hara $\mathrm{P}(0.62 \mathrm{ppm})$ akibat terfiksasi oleh $\mathrm{Al}$ membentuk $\mathrm{Al}\left(\mathrm{H}_{2} \mathrm{PO}_{4}\right)_{3}$ sehingga Ultisols kahat akan unsur $\mathrm{P}$. Selain unsur hara $\mathrm{P}$, unsur hara $\mathrm{N}$ Ultisols penelitian juga tergolong sangat rendah $(0.11 \%)$ disebabkan karena hilang akibat leaching dan sebagian juga dipengaruhi oleh kandungan C-organik yang rendah (1.09\%) (Thomas et al,, 2007). C-organik merupakan salah satu indikator kesuburan tanah dan berkontribusi dalam membantu ketersediaan $\mathrm{N}$ tanah. Kandungan $\mathrm{C}$ organik rendah dikarenakan proses pelapukan bahan organik berjalan cepat akibat curah hujan tinggi didaerah pengambilan sampel tanah.

Berdasarkan Tabel 1, terlihat bahwa pengapuran meningkatkan $\mathrm{pH}$ Ultisols menjadi 5.5. Naiknya $\mathrm{pH}$ disebabkan karena terjadinya hidrolisis kapur dengan air menghasilkan ion $\mathrm{OH}^{-}$. Semakin tinggi konsentrasi ion $\mathrm{OH}^{-}$semakin subur tanah (Thomas et al.,2007). Ion $\mathrm{OH}^{-}$akan 
bereaksi dengan $\mathrm{Al}^{3+}$ di permukaan koloid tanah membentuk Alumunium hidroksida $\mathrm{Al}(\mathrm{OH})_{3}$ sehingga Al terjerap dan konsentrasinya berkurang di tanah $(0.94$ me/100g). Pengapuran juga meningkatkan ketersediaan unsur $\mathrm{P}$ tanah akibat terbentuknya reaksi $\mathrm{Al}(\mathrm{OH})_{3}$ sehingga $\mathrm{Al}$ penyebab fiksasi $\mathrm{P}$ terjerap oleh $\mathrm{OH}^{-}$dan $\mathrm{P}$ terlepas sehingga tersedia di Ultisols (1.45 ppm). Pengapuran tidak menunjukkan adanya pengaruh nyata terhadap peningkatan hara $\mathrm{N}(0.17 \%)$ yang disebabkan karena tidak adanya input bahan organik selama masa inkubasi. Nitrogen pada umumnya berasal dari udara, namun banyak faktor penyebab konsentrasi $\mathrm{N}$ tanah berkurang. Penguapan dan rendahnya kandungan bahan organik menjadi penyebab utama rendahnya ketersediaan $\mathrm{N}$ tanah karena kadar $\mathrm{N}$ anorganik lebih besar bersumber dari bahan organik dari proses mineralisasi ( $\mathrm{Yu}$ et al, 2011). Dari Tabel 1, dapat dilihat bahwa pengapuran mampu meningkatkan konsentrasi kation basa K-dd, Ca-dd dan Mg-dd berturut dengan nilai $0.41,6.21$ dan $2.05 \mathrm{me} / 100 \mathrm{~g}$. Adanya peningkatan jumlah kation basa ini karena pengapuran menyumbangkan sejumlah kation basa terutama $\mathrm{Ca}$ dan $\mathrm{Mg}$ saat terjadinya hidrolisis kapur dengan air. Selain itu, pengapuran meningkatkan kejenuhan basa dan KPK tanah serta meningkatkan ketersediaan $\mathrm{K}$ dan mengurangi pelindian K (Nursyamsi, 2007).

Tabel 1. Hasil analisis ciri kimia Ultisols tanah awal setelah inkubasi kapur

\begin{tabular}{lcccc}
\hline \multicolumn{1}{c}{ Sifat Kimia } & \multicolumn{2}{c}{ Tanah Awal } & \multicolumn{2}{c}{ Inkubasi kapur } \\
& Nilai & Kriteria* & Nilai & Kriteria* \\
\hline PH H ${ }_{2} \mathrm{O}(1: 2)$ & 4.70 & $\mathrm{~m}$ & 5.50 & $\mathrm{am}$ \\
P-tersedia (ppm) & 0.62 & $\mathrm{sr}$ & 1.45 & $\mathrm{sr}$ \\
C-organik (\%) & 1.09 & $\mathrm{r}$ & 1.35 & $\mathrm{sr}$ \\
N-total (\%) & 0.11 & $\mathrm{sr}$ & 0.17 & $\mathrm{r}$ \\
Al-dd (me/100g) & 1.86 & - & 0.94 & - \\
K-dd (me/100g) & 0.28 & $\mathrm{r}$ & 0.41 & $\mathrm{~s}$ \\
Ca-dd (me/100g) & 1.24 & $\mathrm{sr}$ & 6.21 & $\mathrm{~s}$ \\
Mg-dd (me/100g) & 0.45 & $\mathrm{r}$ & 2.05 & $\mathrm{t}$ \\
\hline
\end{tabular}

Keterangan : am= agak masam; $\mathrm{r}=$ rendah; $\mathrm{s}=$ sedang; $\mathrm{t}=$ tinggi; $\mathrm{st}=$ sangat tinggi $*$ Sumber $:$ Balai Penelitian Tanah (2009)

\section{Pertumbuhan Vegetatif Tanaman}

Berdasarkan grafik pada Gambar 2, terlihat perlakuan B merupakan perlakuan bakteri endofit terbaik yang memberikan rata-rata berat kering tertinggi (19.49 g) dibanding perlakuan lain, diikuti dengan perlakuan D $(18.93 \mathrm{~g})$. Hal ini mengindikasikan bahwa perlakuan B dan D yang merupakan perlakuan dengan isolat bakteri endofit dari jaringan akar dan daun tanaman bekerja optimal dalam meningkatkan rata-rata pertumbuhan vegetatif tanaman yang terlihat dari tingginya berat kering tanaman. Selain berat kering, tinggi tanaman, jumlah daun dan jumlah cabang juga menunjukkan peningkatan pertumbuhan dengan pemberian bakteri endofit yang diringi dengan penggunaan pupuk $\mathrm{N} \quad 1 / 2$ rekomendasi. Peningkatan tinggi tanaman, dibanding kontrol tanpa endofit sebesar 16.47 unit (perlakuan B), 6.2 unit 
(perlakuan C) dan 16.4 unit (perlakuan D); jumlah daun 16.33 unit (perlakuan B), 6 unit (perlakuan C) dan 6.5 unit (perlakuan D); jumlah cabang 4.56 unit (perlakuan B), 1.55 unit (perlakuan C) dan 4.39 unit (perlakuan D). Rata-rata pertumbuhan vegetatif tanaman yang meningkat dengan pemberian endofit disebabkan karena kerja dari endofit dalam menstimulasi pertumbuhan tanaman dengan adanya strain promotif yang dihasilkannya. Penelitian Farzana et al (2007) menggunakan bakteri endofit Klebsiella sp. UPM SP9, Erwinia sp. UPM SP10, Azospirillum brasilense SP7, dan Bacillus sphaericus UPMB 10, Azospirillum brasilense SP7, dan Bacillus sphaericus $U P M B \quad 10$ diiringi pemberian tiga rekomendasi pupuk nitrogen $(0,33$, dan $100 \mathrm{~kg} \mathrm{~N} / \mathrm{ha})$ menunjukkan adanya perbedaan yang sangat nyata pada pertumbuhan tanaman ubi jalar. Tanaman yang diinokulasi dengan endofit diiringi dengan pemberian $1 / 3$ dari tingkat normal $\mathrm{N}$ (33 kg N/ha) menghasilkan rata-rata pertumbuhan tanaman dan berat kering akar tertinggi dibandingkan tanpa inokulasi, serta tanaman yang diinokulasi dengan bakteri endofit juga meningkatkan konsentrasi $\mathrm{N}, \mathrm{P}$, dan $\mathrm{K}$ pada tunas dan akar.
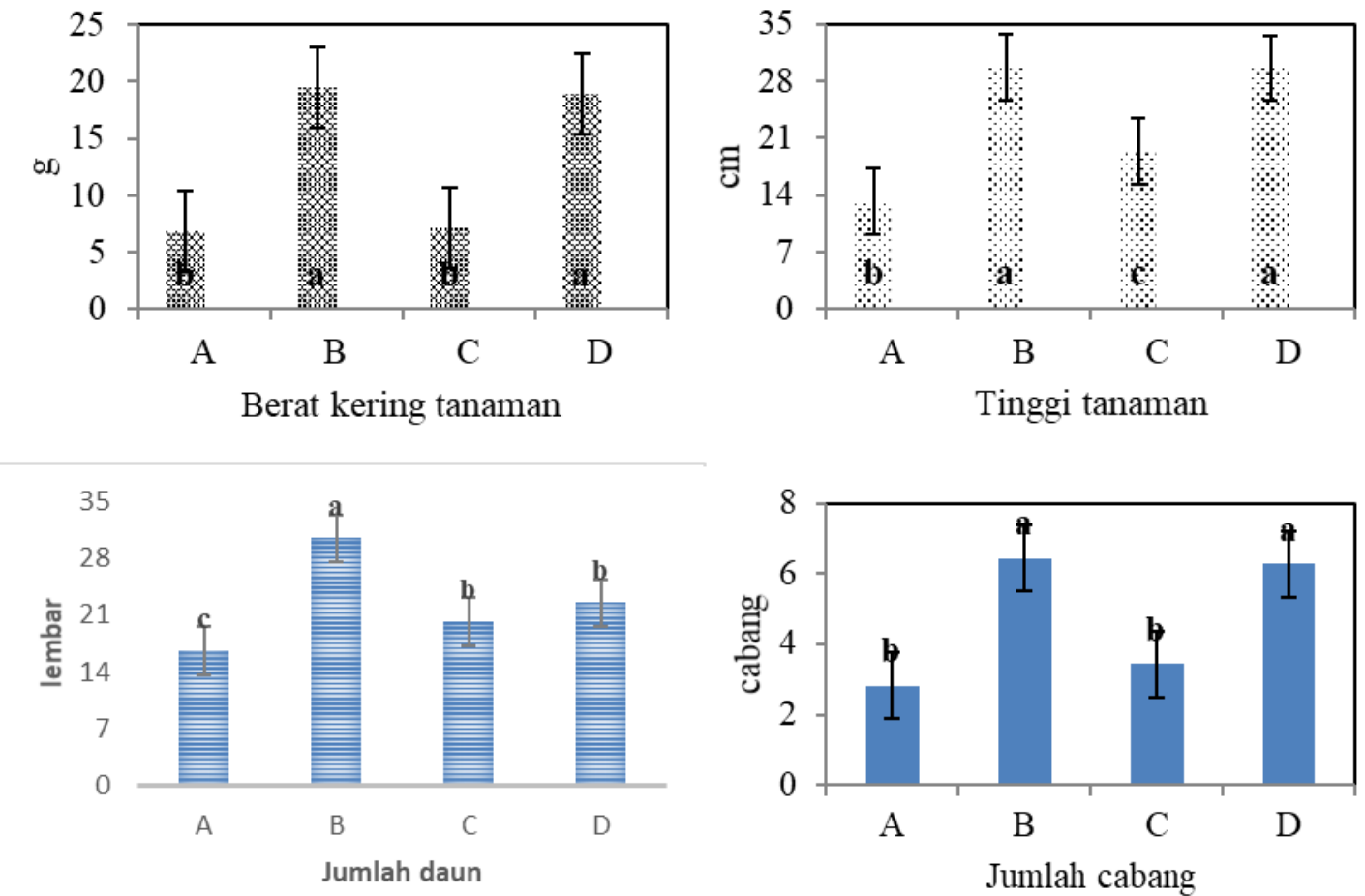

Gambar 2. Pengaruh aplikasi bakteri endofit $(\mathrm{A}=$ tanpa perlakuan endofit; $\mathrm{B}=$ Azospirillum sp $\mathrm{AK}, \mathrm{C}=$ Azospirillum sp $\mathrm{BT}$ dan $\mathrm{D}=$ Azospirillum sp $\mathrm{DN}$ ) terhadap berat kering tanaman, tinggi tanaman, jumlah daun dan jumlah cabang cabai merah. Keterangan: huruf kecil yang sama pada grafik batang pada gambar untuk setiap pengamatan menunjukkan berbeda tidak nyata pada uji DNMRT 5\%. 
Dari 4 perlakuan yang diberikan, terlihat pada perlakuan $\mathrm{C}$ dengan aplikasi endofit BT memperlihatkan pertumbuhan vegetatif tanaman tidak sabaik pada perlakuan B dan D. Ini disebabkan karena kerja bakteri endofit tidak selalu menstimulasi pertumbuhan tanaman melalui sintesis biostimulan dengan produksi auksin, tetapi juga sebagai agen biokontrol dengan menghindari tanaman dari serangan hama dan patogen yang menyebabkan pertumbuhan tanaman terganggu (Kang et al,2010). Selain itu, kelimpahan bakteri endofit pada jaringan batang tidak sebanyak yang ditemukan pada jaringan akar dan daun yaitu $10^{3}-10^{4}$ cfu/g jaringan, ini mengindikasikan perlunya adaptasi tinggi dari bakteri endofit untuk berkembang didalam jaringan tanaman.

Selain pertumbuhan vegetatif tanaman (tinggi tanaman, jumlah daun dan jumlah cabang) yang lebih baik dengan aplikasi endofit, akar tanaman juga memperlihatkan perkembangan lebih optimal dibanding tanpa aplikasi endofit (Gambar 3).

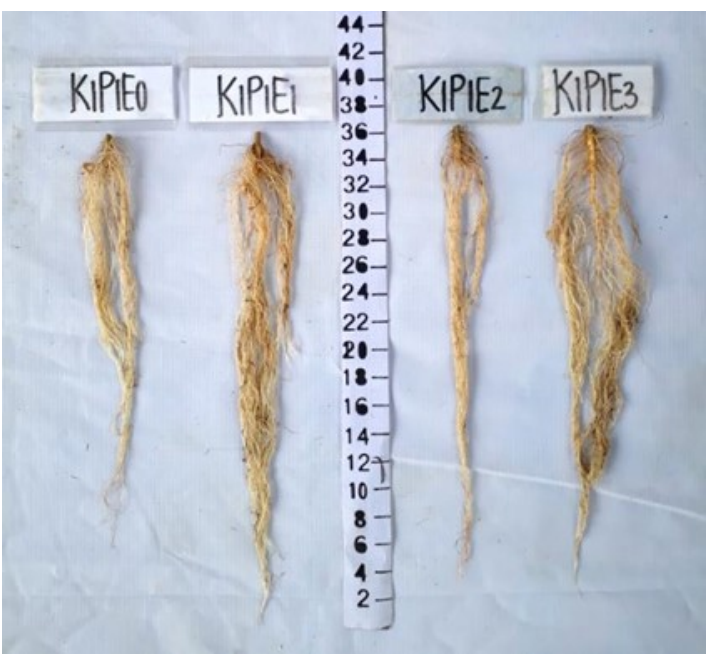

Gambar 3. Pengaruh aplikasi endofit perlakuan $(\mathrm{A}=$ tanpa perlakuan endofit; $\mathrm{B}=$ Azospirillum $\mathrm{sp}$ $\mathrm{AK}, \mathrm{C}=$ Azospirillum sp $\mathrm{BT}$ dan $\mathrm{D}=$ Azospirillum $\mathrm{sp} \mathrm{DN})$ terhadap perkembangan akar cabai merah (Capsicum annum, L).

Dari Gambar 3, terlihat bahwa perlakuan B dan D memberikan perkembangan akar cabai merah yang lebih baik dibanding perlakuan $\mathrm{C}$ dan lebih baik dari perlakuan A tanpa inokulasi endofit. Adanya pengaruh dominan pada isolat bakteri endofit akar dan daun ini diduga karena akar memiliki jumlah endofit yang lebih banyak dibanding jaringan atas permukaan karena tingginya tingkat ketersediaan nutrisi untuk pertumbuhannya, tetapi tidak menutup kemungkinan bakteri endofit juga ditemukan dibagian atas jaringan tanaman. Bakteri endofit yang diisolasi dari jaringan akar dan daun diduga memiliki kemampuan dalam menstimulasi pertumbuhan tanaman melalui aktivitas biostimulan yang dihasilkan. Biostimulan pada bakteri endofit disebabkan dari adanya hormon perangsang tumbuh IAA (indole acetic acid) dan sitokinin yang dihasilkan bakteri yang bekerja secara nyata dalam memacu pertumbuhan tanaman. IAA (indole acetic acid) 
merupakan fitohormon golongan auksin berperan sebagai zat pemacu pertumbuhan tanaman karena dapat meningkatkan sintesis DNA dan RNA (Spaepen et al,2007). IAA banyak ditemukan dijaringan meristem atau jaringan yang aktif membelah seperti ujung akar dan pucuk daun. Auksin membantu pembelahan sel dengan mempengaruhi dinding sel tanaman yang hasilnya mampu memfasilitasi peningkatan jumlah eksudat akar.

\section{KESIMPULAN}

Berdasarkan hasil yang diperoleh dapat disimpulkan bahwa isolat bakteri endofit yang diujicobakan mampu bekerja sebagai biofertilizer dalam memenuhi kebutuhan hara yang berguna pada masa pertumbuhan vegetatif cabai merah. Isolat Azospirillum sp AK dan Azospirillum sp DN memberikan pertumbuhan vegetatif tanaman lebih baik dibanding isolate Azospirillum sp BT dengan berat kering rata-rata secara berurutan yaitu $19.49 \mathrm{~g}$ dan $18.93 \mathrm{~g}$ dengan tinggi $29.67 \mathrm{~cm}$ dan $29.60 \mathrm{~cm}$. Keunggulan ke-2 isolat tersebut juga diperlihatkan pada pengamatan jumlah daun 30.39 helai dan 22.50 helai dan jumlah cabang 6.45 dan 6.28 secara berurutan untuk isolat Azospirillum sp AK dan Azospirillum sp DN.

\section{UCAPAN TERIMAKASIH}

Hasil penelitian yang dilaporkan dalam artikel ini secara finansial didukung oleh Hibah Penelitian Kompetensi DRPM Kemenristekdikti untuk tahun 2019 dengan kontrak (No. T/26/UN.16.17/PT.01.03/PD$\mathrm{PP} / 2019)$.

\section{DAFTAR PUSTAKA}

Badan Pusat Statistik. 2019. Produksi Cabai Indonesia. Jakarta (ID): BPS

Balai Penelitian Tanah. 2009. Analisis Kimia Tanah, Tanaman, Air, Dan
Pupuk. Bogor: Pusat Penelitian dan Tanah agroklimat. Deptan. 215 hal

Farzana Y., Radziah, P., Kamaruzaman, M. S. S. 2007. Effect of PGPR Inoculation on Growth and Yield of Sweetpotato (pp. 421-424). Jurnal of Biological Sciences 7 (2).

Kang, B. G., Kim, W. T., Yun, H. S., and Chang, S. C. 2010. Use of plant growth-promoting rhizobacteria to control stress responses of plant roots. Plant Biotechnology Reports, 4(3), 179-183.

Larran, S., Simón, M. R., Moreno, M. V., Siurana, M. P. S., and Perelló, A. 2016. Endophytes from wheat as biocontrol agents against tan spot disease. Biological Control, 92, 17-23.

Le Cocq, K., Gurr, S. J., Hirsch, P. R., and Mauchline, T. H. 2017. Exploitation of endophytes for sustainable agricultural intensification. Molecular Plant Pathology, 18(3), 469-473.

Leite, D. C. A., Salles, J. F., Calderon, E. N., van Elsas, J. D., and Peixoto, R. S. 2018. Specific plasmid patterns and high rates of bacterial co-occurrence within the coral holobiont. Ecology and Evolution, 8(3), 1818-1832.

Nursyamsi, D., Idris, K., Sabiham, S., Rachim, D. A., and Sofyan, A. 2007. Sifat-sifat tanah dominan yang berpengaruh terhadap $\mathrm{K}$ tersedia pada tanah-tanah yang didominasi. Jurnal Tanah Dan Iklim, 26, 13-28.

Paiman, A., and Armando, Y. G. 2010. Potensi Fisik dan Kimia Lahan Marjinal untuk Pengembangan 
Pengusahaan Tanaman Melinjo dan Karet di Provinsi Jambi. Akta Agrosia, 13(1), 89-97.

Pusat Pengkajian Perdagangan Dalam Negeri. 2019. Analisis Perkembangan Harga Bahan Pangan Pokok di Pasar Domestik dan Internasional. Badan Pengkajian dan Pengembangan Perdagangan Kementrian Perdagangan Republik Indonesia, 2019

Spaepen, S., and Vanderleyden, J. 2011. Auxin and plant-microbe interactions. Cold Spring Harbor Perspectives in Biology, 3(4), 1-13.

Sturz, A. V., Christie, B. R., and Nowak, J. 2000. Bacterial endophytes: Potential role in developing sustainable systems of crop production. Critical Reviews in Plant Sciences, 19(1), 1-30.

Thomas, G. A., Dalal, R. C., and Standley, J. 2007. No-till effects on organic matter, $\mathrm{pH}$, cation exchange capacity and nutrient distribution in a Luvisol in the semi-arid subtropics. Soil and Tillage Research, 94(2), 295-304.

Yu, W., Ding, X., Xue, S., Li, S., Liao, X., and Wang, R. (2013). Effects of organic-matter application on phosphorus adsorption of three soil parent materials. Journal of Soil Science and Plant Nutrition, 13(4), 1003-1017. 